\title{
Accumulation of lead, cadmium, manganese, copper and zinc by sludge worms; Tubifex tubifex in sewage sludge
}

\author{
${ }^{1 *}$ C. C. Kaonga; ${ }^{2}$ J. Kumwenda; ${ }^{3}$ H. T. Mapoma \\ 1*Physics and Biochemical Sciences Department, University of Malawi, The Polytechnic, P/Bag 303, Chichiri, \\ Blantyre 3, Malawi \\ ${ }_{2}^{2}$ Malawi-Liverpool-Wellcome Trust Clinical Research Programme, Chichiri, Blantyre 3, Malawi \\ ${ }^{3}$ Physics and Biochemical Sciences Department, University of Malawi, The Polytechnic, P/Bag 303, Chichiri, \\ Blantyre 3, Malawi
}

Received 10 February 2009; ～revised 26 October 2009; accepted 9 November 2009; available online 1 December 2009

\begin{abstract}
Tubifex tubifex has been shown to survive in organic polluted environments, however, not much has been done on its inorganic pollution tolerance. Samples of T. tubifex and their respective sewage sludge were taken from Soche wastewater treatment plant in Blantyre City, Malawi during July 2007 to November 2008. The total number of sludge samples taken was fifty one which was made into seventeen composite samples. A total of seventeen T. Tubifex samples were also collected. The samples were analyzed for copper, lead, manganese, zinc and cadmium using standard methods from American Public Health Association and Association of Official Analytical Chemists. The concentrations of metals in sewage sludge and T. tubifex were on dry weight basis and the metals determined were acid extractable. In general, heavy metals concentration was lower in T. tubifex than in sewage sludge. The range of heavy metals concentrations were (in sludge and (T. tubifex)): zinc 275.3 - $361.5 \mathrm{mg} / \mathrm{kg}$ (45.0 - 82.2 mg/kg), manganese 293.7 - $230.1 \mathrm{mg} / \mathrm{kg}(1.21$ $3.69 \mathrm{mg} / \mathrm{kg}$ ), copper 86.5 - $120.1 \mathrm{mg} / \mathrm{kg}(1.6-4.7 \mathrm{mg} / \mathrm{kg}$ ), lead $11.2-22.4 \mathrm{mg} / \mathrm{kg}$ (Below detection limit - 0.95 ) and cadmium $1.12-2.31 \mathrm{mg} / \mathrm{kg}(1.08-2.18 \mathrm{mg} / \mathrm{kg})$. The results showed significant differences between the concentrations of manganese, copper, lead and zinc in sewage sludge and T. tubifex $(\mathrm{p}<0.05)$. However there was no significant difference between the concentrations of cadmium in sewage sludge and T. tubifex $(\mathrm{p}>0.05)$. T. tubifex did not show the ability to accumulate heavy metals (attributed to its high defecation and metabolic rate) except for cadmium hence cannot be used as a bioindicator for heavy metal pollution in sludge.
\end{abstract}

Keywords: Biological indicator; Heavy metals; Pollution; T. tubifex; Wastewater treatment plant

\section{INTRODUCTION}

Environmental degradation is a widely recognized global challenge. Some of the problems now affecting the world are acid rain, global warming, hazardous wastes, over population, ozone depletion, smog and water pollution. In Malawi, the major environmental problems are ranked in the order (from more to least important); soil erosion, deforestation, water resources degradation and depletion threat to fish resources, threat to biodiversity, human habitat degradation, high population growth, air pollution and climate change (GoM, 1994).

Environmental pollution is one of the major causes of environmental degradation worldwide. One of the major causes of environmental pollution is the use of

\*Corresponding Author Email: ckawonga1@yahoo.com Tel.: +2658 855 399; Fax: +2651 870578 sewage sludge in agriculture (Nouri, 1980; Nouri et al., 2008). Sewage sludge is the residue from the treatment of domestic and industrial wastewater.

It contains useful organic matter and nutrients for plants. High cost of inorganic fertilizers and high inflation rates in most developing countries have resulted in waste materials like sewage sludge providing an alternative cheap input of nutrients in agriculture (Cooke, 1982). Sewage sludge does not only provide a cheap source of fertilizer, but it also solves the problem of waste disposal and protects the resource base and their reuse. The continual use of sewage sludge can result in accumulation of heavy metals and other toxic materials in soil and crops in particular leafy vegetables (Abdel-Ghani et al., 2007). This can be detrimental to the environment, the production resource base and to 
the consumers of the produce (Alloway and Ayres, 19ШПCampos et al., 2009).

Organisms acquire toxic substances from the environment along with nutrients and water. Some of the poisons are metabolized and excreted, but others accumulate in specific tissues. This capacity is widely recognized as offering one way of monitoring the distribution of toxins in the environment. One of the reasons these toxins are so harmful is that they become more concentrated in successive trophic levels of a food web, a process called biological magnification (Woodwell, 1972; Grimanis et al,. 1978; Adams et al, 1992; Campbell, 1996; Manly, 1996).

Monitoring the distribution of toxins in the environment is important because it provides data required for planning, helps in the determination of the health and condition of a particular environment, provides a means to record environmental changes and trends over time and finally it helps in focusing conservation efforts by relevant authorities towards decision-making (Roth et al., 1997). The use of living organisms to monitor the distribution of toxins in the environment is known as biomonitoring while the organisms are called bioindicators.

Although, there are a number of organisms that can be used as indicators, invertebrates and periphyton are easy to use (Stauber and Florence, 1987; Kaitala, 19ㅁKale, 1998). A number of studies have been done on accumulation of heavy metals by organisms which include Kara (2005) and Kaonga et al. (2008). Examples of invertebrates commonly used as indicators are earthworms, midges and stoneflies. For example, Ireland (1디 and Bamgbose et al. (2000) reported that earthworms could accumulate, in their tissues, heavy metals in contaminated environment. For the terrestrial environment, earthworms are the standard soil toxicity test organism and are ideally suited for assessing the bioavailability of metals, as a result of their ecological importance in most temperate and tropical soils (Spurgeon et al., 2003; Lanno et al., 2004). Closely related to earthworms are Tubifex tubifex.

T. tubifex, also called sludge worm, sewage worm, or lime snake; is a species of tubificid segmented worm that inhabits the sediments of lakes and rivers on several continents. T. tubifex probably includes several species, but distinguishing between them is difficult because reproductive organs, commonly used in species identification, are reabsorbed after mating and also external characteristics of the worm vary with changes in salinity. These worms ingest sediments and gain nutrition by selectively digesting bacteria and absorbing molecules through the body wall. The worms can survive with little oxygen through the use of their hemoglobin rich tail-ends, which they wave in order to absorb oxygen. They can also survive in heavily polluted areas with organic matter that almost no other species can endure. T. tubifex can also survive drought and food shortage by forming a protective cyst and lowering its metabolic rate (Ward, 1997; Suthar and Sing, 2008).

Studies done in Blantyre City, Malawi have already shown that sludge has high heavy metal levels. For example, Kadewa et al. (2001) found levels of copper, cadmium and chromium in soils fertilized by sewage sludge from Soche wastewater treatment plant to be higher than the range for critical concentration for sludge amended soils. However no studies have been done on the accumulation of heavy metals by T. tubifex hence the need for this study which was carried out in Blantyre City, Malawi from July 2007 to November 2008.

\section{MATERIALS AND METHODS}

\section{Study area}

The project was conducted in the city of Blantyre, Malawi from July 2007 to November 2008. Blantyre city is the largest urban settlement in Malawi covering an area of $228 \mathrm{~km}^{2}$. It is the industrial and commercial center of Malawi situated in the Shire Highlands at an altitude of approximately $1150 \mathrm{~m}$ above sea level. It lies at $15^{\circ}$ $47^{\prime} \mathrm{S}, 35^{\circ} 0$ 'E. The samples were taken at Soche waste water treatment plant. Soche wastewater treatment plant was constructed in 1958 and at that time it had only one trickling filter. After 20 years, the plant's capacity to treat wastewater was doubled with the addition of another trickling filter tank. It now serves a population of 24,000 (BCA, 1995). It has to be noted however that during the sampling period only one trickling filter was working.

\section{Sewage sludge sampling}

Sewage sludge eeesamples were collected from the filtering tank. A total of fifty one sewage sludge samples were collected. Three random grab samples were collected from the filtering tank during each sampling session and were mixed in a bucket to make one 
composite sample. The total number of composite samples was therefore seventeen.

\section{T. tubifex sampling}

T. tubifex were collected in the same location as sewage sludge samples above. A total of seventeen T. Tubifex samples were collected for analysis. The T. tubifex samples were collected in $400 \mathrm{~mL}$ plastic bottles into which a few holes were poked on the lid.

\section{Instrumentation}

Atomic absorption spectrophotometer (AAS): GBC 933A AAS model was used for the determination of heavy metals. A glass electrode Sargent-Welch digital pH meter, model Pax S-29998 with pHreading to 0.01 in the range 0 to 14 was used to measure $\mathrm{pH}$.

\section{Sewage sludge preparation and heavy metal determination}

Sewage sludge was dried in a shallow tray left in a well ventilated room until it could be easily ground and sieved. The dry samples were then passed through a 2 $\mathrm{mm}$ sieve and a representative sample (100 g) was retained after quartering and coning (Anderson and Ingram, 1993). Sewage sludge samples were digested using concentrated nitric acid, $\mathrm{HNO}_{3}$ and concentrated hydrochloric acid, $\mathrm{HCl}$. A dried sample (4 g) of sewage sludge was transferred to a round bottom flask and moistened with $3 \mathrm{ml}$ distilled water. For each gram of sample, $7.5 \mathrm{~mL}$ of 6M HCL and $2.5 \mathrm{~mL}$ of concentrated nitric acid were added and the flask was left to stand at room temperature over night. Thereafter, the mixture was boiled gently under reflux for $2 \mathrm{~h}$, cooled and then filtered using a filter paper washed in $\mathrm{HNO}_{3}$. The solution was diluted in a $100 \mathrm{~mL}$ volumetric flask with $\mathrm{HNO}_{3}(2 \mathrm{~mL})$ to volume and the absorbance of the diluted solution was measured using AAS (MAFF, 1987; AOAC, 1990; Alloway以णD).

T.tubifex preparation and heavy metal determination

The T. tubifex were cleaned with distilled water, placed in petri dishes and refrigerated at $10^{\circ} \mathrm{C}$ for $24 \mathrm{~h}$ in order to purge the sludge in the gut. Thereafter they were removed and rinsed slightly with distilled water and then frozen pending analysis. In preparing for analysis, after thawing, $3 \mathrm{~g}$ of the T. tubifex sample (done in triplicates) was weighed and digested with $2 \mathrm{~mL}$ concentrated nitric acid and heated to dryness on a hotplate. The digest was redissolved in $1 \mathrm{~mL}$ concentrated nitric acid (AR) and filtered after which it was made up to $50 \mathrm{~mL}$ with distilled water in a volumetric flask (Bamgbose et al. 2000). The sample was then run on AAS.

\section{Preparation of standard stock solution}

The standard stock solutions of all the metals were prepared as in American Public Health Association (APHA, 1985).

\section{Determination of moisture content in T. tubifex}

About $2.5 \mathrm{~g}$ of the sample was weighed accurately and placed in a pre-weighed crucible. The sample was then placed in an oven and dried for $24 \mathrm{~h}$ at $105^{\circ} \mathrm{C}$. The weights of the sample were recorded before and after the drying and the change in weight were calculated as percentage moisture (AOAC, 1990; Kaeser and Sharpe, 2006). Moisture content determination was done on the same day of sampling.

\section{Determination of sewage sludge $\mathrm{pH}$}

The sample was dissolved in water to form a solution (50:50) and a $\mathrm{pH}$ meter (saturated with potassium chloride, $\mathrm{KCl}$ ) was used to measure $\mathrm{pH}$ (AOAC, 1990).

\section{Data analysis}

Data was analyzed using statistical package for social scientists (SPSS) windows program, version 11.5 (Independent sample t- test) and microsoft excel windows program (Pearson correlations and ranges). Independent sample t-test was chosen because it was assumed that the samples were different from each other. Pearson correlations were used because it was assumed that the levels of heavy metals in sewage sludge were linearly related to those found in T. tubifex.

\section{RESULTS AND DISCUSSION}

Moisture content of T. tubifex

The moisture content of T. tubifex ranged from $70-$ $79 \%$ with an average of $74 \%$ (Table 1 ). This is not significantly different from studies that were done on earthworms in which it was found that they contained moisture content of $75 \%$ (Beyer, 1996).

\section{pH of sewage sludge}

The range of $\mathrm{pH}$ in sludge was 7.3 to 8.9 (Fig. 1). This range is not conducive to the availability of cations. Penney (2004) and Iretskaya and Chien (1999) declare that the $\mathrm{pH}$ is the most important parameter that governs the adsorption of inorganic ions. One reason is that a large part of the particle charge is variable, 
and therefore electrostatic attraction is different depending on the $\mathrm{pH}$ value. Hence anions are adsorbed more strongly at low $\mathrm{pH}$ (when the oxides contain many positively charged groups) whereas cations are more strongly sorbed at high $\mathrm{pH}$ (because humic substances and oxides become more negatively charged). However the $\mathrm{pH}$ range was conducive for the survival of $T$. tubifex which can tolerate pollution more than earthworms. Earthworms prefer a pH range of 6.5 to 7.5.

Zinc levels in sewage sludge and T. tubifex

The range of zinc concentration in sludge was $275.3-361.5 \mathrm{mg} / \mathrm{kg}$ while for T. tubifex it was $45.0-82.2 \mathrm{mg} / \mathrm{kg}$ (Table 2). The levels of zinc in sewage sludge were significantly higher than those in T. tubifex $(\mathrm{p}<0.05)$ (Table 2). Sewage sludge and T. tubifex zinc levels were not strongly correlated $(r=0.016)$. The mean concentration of zinc in sewage sludge was lower than that found by Kadewa et al. (2001) (374.4 mg/kg as compared to $308.4 \mathrm{mg} / \mathrm{kg}$ ) who analyzed heavy metals in sludge from the same sampling area (the research was about sludge utilization in agriculture whereby he used the sludge in vegetables as a fertilizer and determined heavy metal content). This is attributed to the fact that only one trickling filter was working during the time this study was conducted as such their could be a dilution effect on the waste water treatment facility as it is handling the load for two components. The levels of zinc in sludge were lower than the maximum permissible levels from other countries (Table 1) which was also the case with the study done by Kadewa $e t$ al. (2001). The presence of zinc in sewage sludge is due to corrosion of galvanized iron in the domestic plumbing systems (Koch and Rotard, 2001). The presence of Queen Elizabeth Central hospital which also releases part of its waste water into the municipal sewer line, might also be contributing to zinc levels in sewage sludge. Tolosana and Ehrlich (2000) found that effluent from medical institutions in South Africa had higher levels of zinc. This is compounded by the use of shampoos to combat dandruff which can contain up to $0.5 \% \mathrm{Zn}$ as an active ingredient (Leeper, 1978). In Blantyre, there are a lot of hair dressing saloons whose zinc contribution to wastewater may be significant.

\section{Manganese levels in sewage sludge and T. tubifex}

The range of manganese concentration in sludge was $293.7-230.1 \mathrm{mg} / \mathrm{kg}$ while for T. tubifex it was 1.21 -
$3.69 \mathrm{mg} / \mathrm{kg}$ (Table 2). The results showed significantly higher $(p<0.05)$ concentrations of manganese in sewage sludge than in T. tubifex (Table 2). Sewage sludge and T. tubifex manganese levels were not strongly correlated and showed an inverse relationship i.e. as the levels were increasing in sludge there was a decreasing trend in T. tubifex $(\mathrm{r}=-0.012)$. The mean levels of manganese in sludge were lower than that found by Kadewa et al. (2001) $(323.3 \mathrm{mg} / \mathrm{kg}$ as compared to $254.3 \mathrm{mg} / \mathrm{kg}$ ) which is also attributed to dilution. The maximum permissible levels of manganese in sewage sludge for other countries were not available. Manganese is used in industrial processes and in various consumer products. The sources of manganese in sewage sludge are effluents from alloy, steel and iron production (Jaques, 1987 and Moore, 1991).

\section{Copper levels in sewage sludge and T. tubifex}

The range of copper concentration in sludge was $86.5-120.1 \mathrm{mg} / \mathrm{kg}$ while for $T$. tubifex it was $1.6-4.7$ $\mathrm{mg} / \mathrm{kg}$ (Table 2). The results showed significantly higher $(\mathrm{p}<0.05)$ levels of copper in sewage sludge than T. tubifex. Sewage sludge and T. tubifex copper levels were not strongly correlated $(r=0.092)$. The mean copper sludge levels were lower than those found by Kadewa et al. (2001) (122.0 mg/kg as compared to 101.97 $\mathrm{mg} / \mathrm{kg}$ ) which is also attributed to dilution. The levels were also below the maximum acceptable limits from other countries (Table 2). The presence of copper in sludge may be due to corrosion of copper plumbing systems (Koch and Rotard, 2001). The presence of Queen Elizabeth Central Hospital might also be contributing to copper levels in sludge. Tolosana and Ehrlich (2000) found that the effluent from medical institutions in South Africa contained high levels of copper.

\section{Lead levels in sewage sludge and T. tubifex}

The range of lead concentration in sludge was 11.2 - $22.4 \mathrm{mg} / \mathrm{kg}$ while for T. tubifex it was from below detection limit $-0.95 \mathrm{mg} / \mathrm{kg}$ (Table 2). The results showed significantly higher $(\mathrm{p}<0.05)$ levels of lead in sewage sludge than in T. tubifex. Sewage sludge and $T$. tubifex lead levels were not strongly correlated $(\mathrm{r}=$ -0.082 ) and also showed an inverse relationship i.e. as the levels of lead were increasing in sludge it was not the same case for T. tubifex. The mean lead levels in sludge were slightly lower than those found by Kadewa 
et al. (2001) (61.1 mg/kg as compared to $16.353 \mathrm{mg} / \mathrm{kg})$ which is attributed to dilution and also the banning of leaded petrol in Malawi. The lead values in sludge were below the maximum permissible limits from other countries (Table 2). Sewage sludge is not the only source of lead into soils. For example, Grandjean, (1992) reported that lead in soil results from various municipal and industrial wastes, automobile emissions, decomposition of paints in aged homes and sewage waste.

Cadmium levels in sewage sludge and T. tubifex

The range of cadmium concentration in sludge was $1.12-2.31 \mathrm{mg} / \mathrm{kg}$ while for $T$. tubifex it was $1.08-2.18$ $\mathrm{mg} / \mathrm{kg}$ (Table 2). The results showed no significant differences $(\mathrm{p}<0.05)$ for cadmium in sewage sludge as compared to T. tubifex. Correlations showed an inverse relationship of cadmium levels in sewage sludge and $T$. tubifex $(\mathrm{r}=-0.174)$ i.e. as the levels were increasing in sludge it was not the case in T. tubifex. These results were not very different from Kadewa (2001). Kadewa reported a mean of $1.42 \mathrm{mg} / \mathrm{kg}$ of cadmium for Soche sewage sludge as compared to $1.644 \mathrm{mg} / \mathrm{kg}$ for this study. Cadmium in sewage sludge may have come from fertilizer producing industries and the use of cadmium
Table 1:Moisture content in T.tubifex

\begin{tabular}{lc}
\hline Sample No. & Moisture content (\%) \\
\hline 1 & 74 \\
2 & 73 \\
3 & 72 \\
4 & 79 \\
5 & 73 \\
6 & 79 \\
7 & 75 \\
8 & 70 \\
9 & 75 \\
10 & 73 \\
11 & 77 \\
12 & 74 \\
13 & 76 \\
14 & 77 \\
16 & 71 \\
17 & 70 \\
\hline
\end{tabular}

batteries. The cadmium levels in sewage sludge were low as compared to the maximum acceptable limits from other countries (Table 2). In earthworms studies, cadmium tends to be more mobile in soils and therefore more available to earthworms than other heavy metals (Ma, 2004). The apparent ability to accumulate high concentrations of cadmium in earthworms is related to the induction of cadmium-binding proteins with the

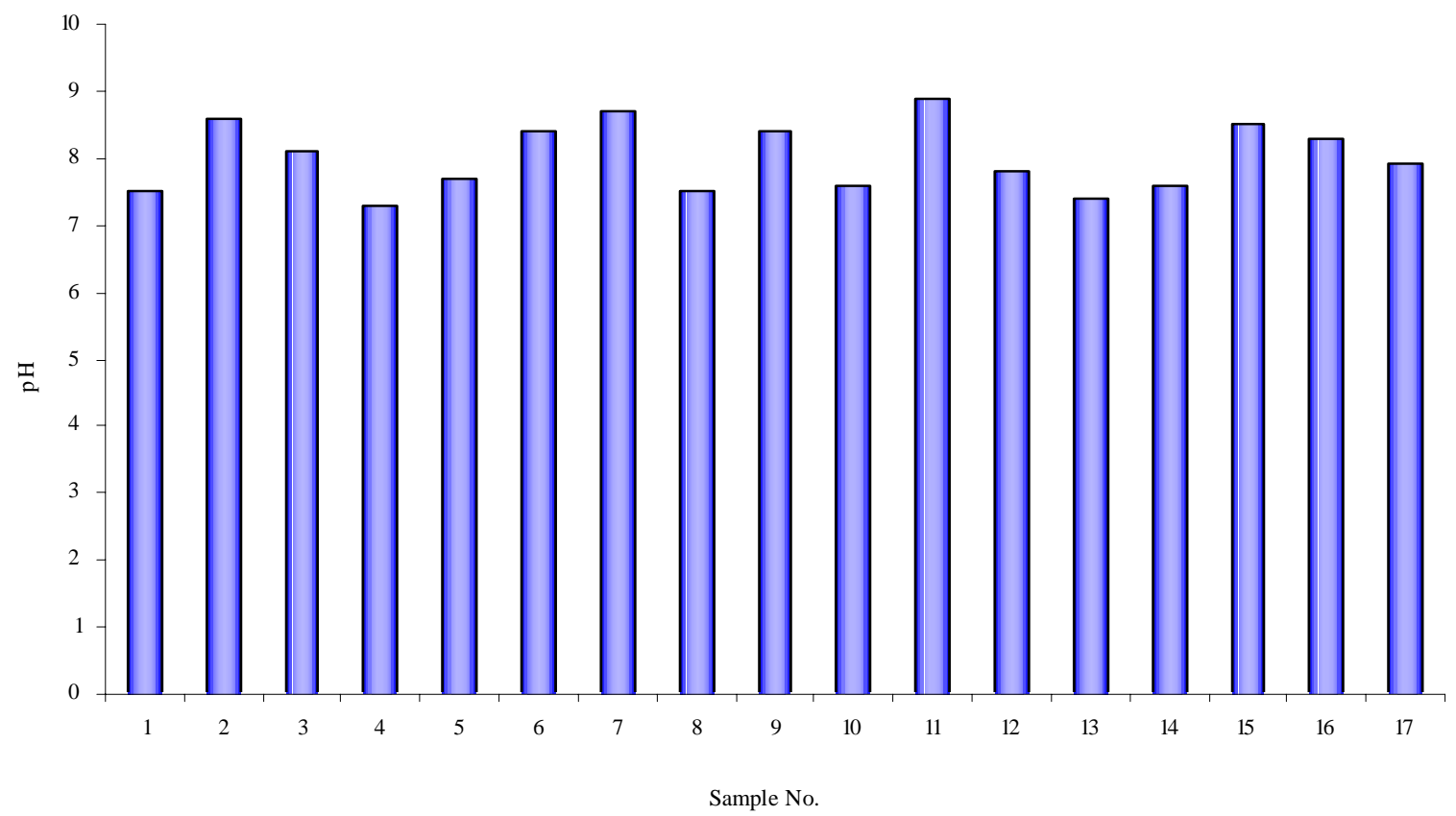

Fig. 1: Sludge $\mathrm{pH}$ levels 


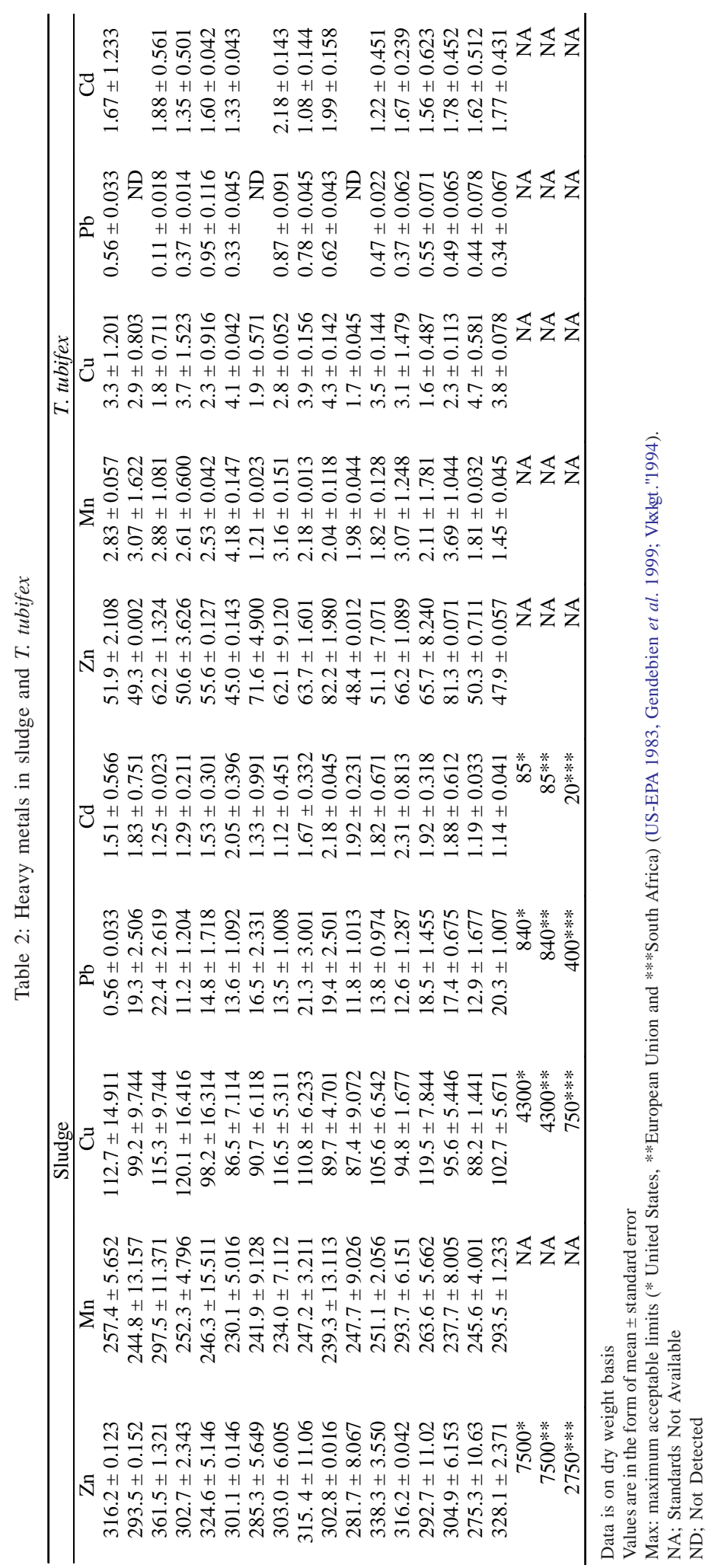


characteristics of metallothioneins and also sequestration of cadmium by isomers of proteins (Suzuki et al., 1980; Morgan et al., 1999). This could also be the case with T. tubifex. The inability of T. tubifex to accumulate the other heavy metals could be attributed to its high metabolic and defecation rate. For example, Volpers and Neumann (2005) found that T. tubifex, had a defecation rate (which is correlated with metabolic rate) always slightly higher than that of Limnodrilus hoffmeisteri (another Tubificid species).

\section{CONCLUSION}

The study generally found that the concentration of heavy metals in T. tubifex was lower than that of sewage sludge. The results showed that $T$. tubifex cannot be used as an indicator of general heavy metal pollution in sewage sludge except for cadmium. The study recommended that the local assembly should look at possible ways of monitoring heavy metals in sewage sludge. Guidelines should also be devised for the utilization of sewage sludge in Malawi in line with the quality of the sludge.

\section{ACKNOWLEDGEMENTS}

The authors would like to thank the Polytechnic University of Malawi for funding this research. They are also very grateful to the Department of Physics and Biochemical Sciences at the same institution for providing laboratory space. Last but not least, they would like to thank the Blantyre City Assembly for allowing them to get samples from their wastewater treatment plant.

\section{REFERENCES}

Abdel-Ghani, N. T.; Hefny, M.; El-Chaghaby, G. A. F., (2007). Removal of lead from aqueous solution using low cost abundantly available adsorbents. Int. J. Environ. Sci. Tech., 4 (1), 67-74 (8 pages).

Adams, W. J.; Kimerle, R. A.; Barnet, J. W., (1992). Sediment quality and aquatic life assessment. Environ. Sci. Tech., 26 (10), 1865-1875 (11 pages).

Alloway, B. J., (1995). Heavy metals insoils, $2^{\text {nd. }}$ Ed., Blackie Academic and Professionals, London, UK

Alloway, B. J.; Ayres, D. C., (1997). Chemical principles of environmental pollution $2^{\text {nd. }}$ Ed., Blackie Academic and Professional, London, UK.

Anderson, J. M.; Ingram, J. S. I., (1993). Tropical soil biology: A Handbook of Methods $2^{\text {nd. }}$ Ed. CAB International, UK.

APHA., (1985). Standard methods for the examination of water and wastewater $16^{\text {th. }}$ Ed. American Public Health Association, Washington DC, USA.

AOAC., (1990). Official methods of analyses $15^{\text {th. }}$ Ed., Association of Official Analytical Chemists, New York, USA.
Bamgbose, O.; Odukoya, O.; Arowolo, T. O. A.,(2000). Earthworms as bio-indicators of heavy metal pollution in dumpsites of Abeokuta city. Nigeria. Rev. Biol. Trop., 48 (1), 229-234 (6 pages).

Beyer, W. N., (1996). Accumulation of chlorinated benzenes in earthworms. bulletin of environ. Contamin. Toxicol., 57 (5), $729-736$ (8 pages).

BCA., (1995). Sanitation masterplan study for city of Blantyre; existing sanitation situation. Vol .1. Blantyre City Assembly, Carl Bro International A/S in association with BNM Consortium.

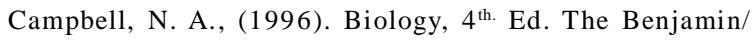
cummingspublishing company Inc., University of California, USA.

Campos, J. L.; Oteroa, L.; Francoa, A.; Mosquera-Corrala, A.; Rocaa, E., (2009). Ozonation strategies to reduce sludge production of a seafood industry WWTP. Bioresour. Tech., 100 (3), 1069-1073 (5 pages).

Cooke, G. W., (1982). Fertiizing for maximum yield $3^{\text {rd. Ed., }}$ Granada Publishing Limited, London.

Gendebien, A. H.; Cartmell, E.; Chambers, B. J.; Nicholson, F. A.; Aitken, M. N., (1999). Beneficial effects of biosolids on soil quality and fertility. SAC/SEPA Conference, Edinburgh, Scotland.

Grandjean, P., (1992). Health significance of metals, in: Maxcy Rosenau Last, (Eds.), Public health and preventive medicine. Prentice-Hall International Inc, London, UK

Grimanis, A. P.; Zafiropoulos, D.; Vassilaki, R.; Grimanis, M., (1978). Trace elements in the flesh and liver of two fish species from polluted and unpolluted areas in the Aegean Sea. Environ. Sci. Tech., 12 (6), 723-726 (4 pages).

GoM., (1994). National environmental action plan: The action plan.Vol. 1. Government of Malawi, Department of Environmental Affairs, Lilongwe, Malawi.

Ireland, M. P., (1983). Heavy metal uptake and tissue distribution, in: Satchell, J. E., (Eds.), Earthworms ecology, from Darwin to vermi culture. Chapman and Hall, London, UK.

Iretskaya, S. N.; Chien, S .H., (1999). Comparison of cadmium uptake by five different food grain crops grown on three soils of varying pH. Comm. Soil Sci. Plant Anal., 30 (3-4), 441448 (8 pages).

Jaques, A. P., (1987). National inventory of sources and emissions of manganese. Report EPS 5/MM/1. Ministry of Supply and Services, Canada.

Kadewa, W. W.; Henry, E. M.; Masamba, W. R. M.; Kaunda, C. C., (2001). Impact of sewage sludge application to horticulture: A case of the city of Blantyre, in: Proceedings of the First Chancellor College Research Dissemination Conference. Zomba, Malawi

Kaitala, S., (1988). Multiple toxicity and accumulation of heavy metals in two bivalve mollusc species. Water Sci. Tech., 20 (6-7), 23-32 (10 pages).

Kale, R. D., (1998). Earthworms: Natures gift for utilization of organic wastes. Earthworms ecology. CRC Press, Boca Raton FL, 355-377.

Kaeser, A. J.; Sharpe, W. E., (2006). Patterns of distribution and abundance of Tubifex tubifex and other aquatic Oligochaetes in Myxobolus cerebralis enzootic areas in Pennsylvania. J. Aquat. Anim. Health, 18 (1), 64-78 (15 pages).

Kaonga, C. C.; Chiotha, S .S.; Monjerezi, M.; Fabiano, E.; Henry, E .M., (2008). Levels of cadmium, manganese and lead in 
water and algae Spirogyra aequinoctialis. Int. J. Environ. Sci. Tech., 5(4), 471-478 (8 pages)

Kara, Y., (2005). Bioaccumulation of $\mathrm{Cu}, \mathrm{Zn}$ and $\mathrm{Ni}$ from the wastewater by treated Nasturtium officinale. Int. J. Environ. Sci. Tech., 2 (1), 63-68 (6 pages)

Koch, M.; Rotard, W., (2001). On the contribution of background sources to the heavy metal content of municipal sewage sludge. Water Sci. Tech., 43 (2), 67-74 (8 pages).

Lanno, R.; Wells, J.; Conder, J.; Bradham, K.; Basta, N., (2004). The bioavailability of chemicals in soil for earthworms. Ecotox. Environ. Safe., 57 (1), 39-47 (9 pages).

Leeper, G. W., (1978). Managing the heavy metals on the land. Pollution. Engineering and Tech., Vol. 6. Marcel Dekker Inc., New York, USA.

Ma, W. C., (2004). Estimating heavy metal accumulation in oligochaete earthworms: A meta- analysis of field data. Bull Environ. Contamin. Toxicol., 72 (4), 663-670 (8 pages).

MAFF., (1987). Methods for the determination of metals in soils, sediments, sewage sludge and plants by hydrochloricnitric acid digestion. Ministry of Agriculture, Food and Fisheries, HMSO, UK.

Manly, R., (1996). Biological indicators, in: Fifield, F.W., Haines, P.J. (Eds.). Environmental analytical chemistry. Black Academic and Professional, Oxford, London.

Morgan, A. J.; Stürzenbaum, S. R.; Kille, P., (1999). A short overview of molecular biomarker strategies with particular regard to recent developments on earthworms. Pedobiologia., 43 (6), 574-584 (11 pages).

Moore, J. W., (1991). Inorganic contaminants of surface water: Research and monitoring priorities.Springer-Verlag, New York, USA

Nouri, J. (1980). Heavy metals in sewage sludge, soils amended with sludge and their uptake by plants. Ph.D. dissertation, Westfield College, University of London.

Nouri, J.; Mahvi, A. H.; Jahed, G.R.; Babaei, A. A., (2008). Regional distribution pattern of groundwater heavy metals resulting from agricultural activities. Environ. Geo., 55 (6), 1337-1343 (7 pages).

Penney, D., (2004), Micronutrients, agriculture, food and rural development, Alberta Government. http://www1.agric. gov.ab.ca/\$department/deptdocs.nsf/all/aesa 1851 ?opendocument

Roth, D.; Fay, L.; Moyer, K.; Warne, R., (1997). Environmental lands acquisition and maintenance strategy discussion paper. South West Florida Water Management District, (SWFWMD).

Spurgeon, D. J.; Weeks, J. M.; Van Gestel, C. A. M., (2003). A summary of eleven years progress in earthworm ecotoxicology. Pedobiologia., 47 (5-6), 588-606 (19 pages).

Stauber, J. L.; Florence, T. M., (1987). Mechanism of toxicity of ionic copper and copper complexes to algae. Marine Biol., 94 (4), 511-519 (9 pages).

Suthar, S.; Singh, S., (2008). Vermicomposting of domestic waste by using two epigeic earthworms (Perionyx excavatus and Perionyx sansibaricus). Int. J. Environ. Sci. Tech., 5 (1), 99-106 (8 pages).

Suzuki, K. T.; Yamamura, M.; Mori, T., (1980). Cadmiumbinding proteins induced in the earthworm. Arch. Environ. Cont. Toxicol., 9(4), 415-424 (10 pages).

Tolosana, S.; Erhlich, R., (2000). Composition of liquid effluent discharged by medical institutions in Cape Town. S. Afr. J. Sci., 96 (8), 417-420 (4 pages).

US EPA., (1983). Land application of municipal sludge; Process design manual.United States Environmental Protection Agency, Cincinnati, USA.

Vivier, F. S., (1994). Wastewater use activities in South Africa. WHO-Afro Regional Workshop on Health, Agriculture and Environmental Aspects on the Use of Wastewater. Harare, Zimbabwe, Oct. 31- Nov.

Volpers, M.; Neumann, D., (2005). Tolerance of two tubificid species (Tubifex tubifex and Limnodrilus hoffmeisteri) to hypoxic and sulfidic conditions in novel, long- term experiments. Archiv für Hydrobiologie, 164 (1), 13-38 (25 pages).

Ward, S., (1997). Worms in the aquarium part one: Tubifex. (Downloaded: January, 14, 2009,

Woodwell, G. M., (1972). A watch on the earth; Man’s home series. United Nations Conference on the Human Environment. Stockholm, Sweden.

AUTHOR (S) BIOSKETCHES

Kaonga, C. C., M.Sc., Department of Physics and Biochemical Sciences, University of Malawi, The Polytechnic, P/Bag 303, Chichiri, Blantyre 3, Malawi. Email: ckawonga1@yahoo.com

Kumwenda, J., B.Sc., Malawi-Liverpool-Wellcome Trust Clinical Research Programme, P.O. Box 30096, Chichiri, Blantyre 3, Malawi. Email: kumwendajean@yahoo.co.uk

Mapoma, H. T., M.Sc., Department of Physics and Biochemical Sciences, University of Malawi, The Polytechnic, P/Bag 303, Chichiri, Blantyre 3, Malawi. Email: hmapoma@poly.ac.mw

How to cite this article: (Harvard style)

Kaonga, C. C.; Kumwenda, J.; Mapoma, H. T., (2010). Accumulation of lead, cadmium, manganese, copper and zinc by sludge worms; Tubifex tubifex in sewage sludge. Int. J. Environ. Sci. Tech., 7 (1), 119-126. 